\title{
Singlet Oxygen Toxicity Is Cell Line-dependent: A Study of Lipid Peroxidation in Nine Leukemia Cell Lines
}

\author{
Freya Q. Schafer* and Garry R. Buettner \\ Free Radical Research Institute \& ESR Facility, The University of lowa, lowa City, IA, USA
}

Received 3 June 1999; accepted 7 September 1999

\begin{abstract}
Singlet oxygen $\left({ }^{1} \mathrm{O}_{2}\right)$ can be quenched by water, lipids, proteins, nucleic acids and other small molecules. Polyunsaturated fatty acids (PUFA) of cells principally quench ${ }^{1} \mathrm{O}_{2}$ by chemical mechanisms, producing lipid hydroperoxides, while proteins physically and chemically quench ${ }^{1} \mathrm{O}_{2}$. Because cell lines can have different PUFA and protein levels, we hypothesized that ${ }^{1} \mathrm{O}_{2}$ toxicity will vary between cell lines. We used Photofrin ${ }^{\circledR}$ as a source of ${ }^{1} \mathrm{O}_{2}$. Exposure of nine different leukemia cell lines (CEM, HEL, HL-60, K-562, KG-1, L1210, Molt-4, THP1 and U-937) to Photofrin and light results in changes in membrane permeability (trypan blue) that vary with cell line. The greater the lipid content of the cell line, the less susceptible they are to membrane damage. When the cell media was supplemented with docosahexaenoic acid (DHA, 22:6), the overall unsaturation of cellular lipids increased. Photofrin and light resulted in increased radical formation in these supplemented cells compared to controls; however, there was no difference in membrane permeability between DHA-supplemented and control cells. Lipid-derived radical formation (electron paramagnetic resonance spin trapping) was cell line dependent; but no correlation between lipid content of cells and radical formation was found. However, we found that the greater the protein content of cells the more they were protected against membrane damage induced by Photofrin photosensitization. This suggests that cellular proteins are a key target for ${ }^{1} \mathrm{O}_{2}$-mediated toxicity. A remarkable observation is that cell size correlates inversely with ability of cells to cope with a given flux of ${ }^{1} \mathrm{O}_{2}$.
\end{abstract}

\section{INTRODUCTION}

Singlet oxygen $\left({ }^{1} \mathrm{O}_{2}\right) \dagger$ generated in biological systems can serve as a signaling molecule as well as an initiator of det-

\footnotetext{
*To whom correspondence should be addressed at: Free Radical Research Institute, EMRB 68, The University of Iowa, Iowa City, IA 52242-1101, USA. Fax: 319-335-8039; e-mail: freya-schafer@uiowa.edu

$\dagger$ Abbreviations: ATCC, American Type Culture Collection; DBI, double bond index, the average number of double bonds per fatty acid chain in a cell; DHA, docosahexaenoic acid; EPR, electron paramagnetic resonance; FBS, fetal bovine serum; 10\% FBS-

(c) 1999 American Society for Photobiology 0031-8655/99 $\$ 5.00+0.00$
}

rimental biological oxidations (1). It can be produced by photosensitization with Photofrin ${ }^{\circledR}$. Photofrin is a clinically approved photosensitizer used in the photodynamic therapy (PDT) of various types of cancer. It is a hydrophobic, hematoporphyrin derivative that locates in cell membranes, where, upon light exposure, it produces singlet oxygen $(2,3)$. Singlet oxygen reacts with polyunsaturated fatty acids (PUFA) in the cell membrane to form lipid hydroperoxides (4). Ferrous iron can act as a catalyst and initiate the breakdown of lipid hydroperoxides via a radical chain reaction. This chain reaction produces reactive oxygen species, aldehydes and other toxic products that can lead to cell death (5-7).

Both the protein and PUFA content of different cell lines can vary greatly. Various amino acids can quench ${ }^{1} \mathrm{O}_{2}$ physically; e.g. histidine has a rate constant of $\left(k=10^{7}-10^{8} \mathrm{M}^{-1}\right.$ $\mathrm{s}^{-1}$ ) (8); however tryptophan, methionine and cysteine chemically quench ${ }^{1} \mathrm{O}_{2}$ resulting in protein damage (9-11). It has been shown that proteins can dominate the quenching of ${ }^{1} \mathrm{O}_{2}$ in the membrane and the cytosol $(12,13)$. However, PUFA are also susceptible targets for ${ }^{1} \mathrm{O}_{2}$. The oxidizability of PUFA by ${ }^{1} \mathrm{O}_{2}$ will be proportional to the double bound index (DBI). The DBI is the average number of double bonds per fatty acid chain in the cell (14). Thus, a logical hypothesis is that cells with a higher DBI should be more sensitive to ${ }^{1} \mathrm{O}_{2}$ phototoxicity compared to cells with low PUFA content.

The goal of this study was to investigate the toxicity of ${ }^{1} \mathrm{O}_{2}$ in various tumor cells and to determine the influence of the different PUFA and protein content of the cells on lipidderived radical formation and membrane permeability. To examine this, nine different leukemia cells were characterized for protein and lipid content and subjected to Photofrin photosensitization. Lipid-derived radical formation was detected by electron paramagnetic resonance (EPR) spin trapping with $\alpha$-(4-pyridyl-1-oxide)- $N$-t-butylnitrone (POBN) and membrane permeability was determined by trypan blue dye exclusion.

\section{MATERIALS AND METHODS}

Chemicals. Photofrin (porfimer sodium) was kindly provided by QLT Phototherapeutics, Inc., Vancouver, BC, Canada. It was dissolved in $5 \%$ dextrose $(\mathrm{pH} 7.4)$ and frozen at $-20^{\circ} \mathrm{C}$.

RPMI, RPMI-1640 medium with $10 \%$ fetal bovine serum; FSC, forward scatter; GPx glutathione peroxidase- $1 ;{ }^{1} \mathrm{O}_{2}$, singlet oxygen; PBS, phosphate-buffered saline; PDT, photodynamic therapy; POBN, $\alpha$-(4-pyridyl-1-oxide)- $N$ - $t$-butylnitrone; PUFA, polyunsaturated fatty acids; SSC, orthogonal light scatter. 
Table 1. Size of nine leukemia cell lines

\begin{tabular}{|c|c|c|c|c|}
\hline $\begin{array}{l}\text { Cell } \\
\text { line }\end{array}$ & $\begin{array}{c}\text { Median } \\
\text { diameter }(\mu \mathrm{m})\end{array}$ & $\begin{array}{l}\mathrm{SD}^{* \dagger} \\
( \pm \mu \mathrm{m})\end{array}$ & $\begin{array}{c}\text { Range* } \\
(\mu \mathrm{m})\end{array}$ & $\begin{array}{c}\text { Ranget: } \\
(\mu \mathrm{m})\end{array}$ \\
\hline CEM & $9 \S$ & 1.8 & $5.2-14.1$ & $8-12$ \\
\hline HEL & $12.1 *$ & 1.3 & $9.1-15.8$ & $10-18$ \\
\hline HL-60 & $10 \S$ & 1.4 & $6.1-13.6$ & $8-12$ \\
\hline K-562 & $14.3 *$ & 1.6 & $9.3-18.7$ & $10-20$ \\
\hline KG-1 & $10.3^{*}$ & 1.4 & $6.1-13.3$ & $8-18$ \\
\hline L1210 & $10.4 *$ & 1.1 & $7.5-13.3$ & $8-10$ \\
\hline Molt-4 & $11.4 *$ & 1.3 & $8.5-15.5$ & $10-12$ \\
\hline THP-1 & $12.5^{*}$ & 1.4 & $9.2-16.6$ & $8-12$ \\
\hline U-937 & $13.0 \S$ & 1.8 & $9.1-18.3$ & $8-18$ \\
\hline
\end{tabular}

*These values were determined from the FSC measured by flow cytometry, using the equation: cell diameter $=(0.0893 \cdot$ FSC $0.677) \mu \mathrm{m}$.

$\dagger$ The standard deviation (SD) of the cell diameter distribution was determined from the gaussian FSC distribution. Using the equation above $\left(\mathrm{FSC}_{\text {median }} \pm \mathrm{SD}_{\mathrm{FSC}}\right)$ was converted to cell diamters. The SD in $\mu \mathrm{m}$ is then estimated as the range of these two values/2.

$\ddagger$ These values were determined using a micrometer and conventional light microscopy.

$\S$ These diameters were determined using conventional light microscopy and were used as standards for the flow cytometric determinations.

Phosphate-buffered saline (PBS), $210 \mathrm{mg}$ potassium dihydrogen phosphate, $407 \mathrm{mg}$ sodium monohydrogen phosphate and $9 \mathrm{~g}$ sodium chloride $(0.9 \%)$ were dissolved in $1 \mathrm{~L}$ water and adjusted to pH 7.4 with $1 N$ HCI. Both the sodium chloride and the PBS solution were sterile filtered and stored over chelating resin (Sigma) to minimize the level of adventitious transition metals (15). $\alpha$-(4-Pyridyl1-oxide)- $N$ - $t$-butylnitrone (Aldrich) was prepared as a $1 M$ stock solution in distilled water. Ascorbic acid $(10 \mathrm{mM})$ and $\mathrm{FeSO}_{4} \cdot 7 \mathrm{H}_{2} \mathrm{O}$ $(1 \mathrm{~m} M)$ stock solutions in distilled water were prepared just before each experiment. Scintigest was from Fisher.

Cell culture. Leukemia cells were acquired from the American Type Culture Collection (ATCC). HL-60 stock cells were grown in medium consisting of RPMI-1640 medium (Gibco) and 10\% fetal bovine serum (10\% FBS-RPMI) supplemented with L-glutamine (2 $\mathrm{mM}$ ); THP-1 and KG-1 stock cells required the addition of 2-mercaptoethanol to $10 \%$ FBS-RPMI medium. All other leukemia cells were grown in $10 \%$ FBS-RPMI medium. The HL-60, THP1 and KG1 cells were grown in 10\% FBS-RPMI medium for at least 3 days before the experiment. Experiments were done in exponential growth phase.

Cell size. Unstained cells $\left(1 \times 10^{6}\right.$ cells/mL RPMI medium $)$ were imaged on a Leitz Diaplan microscope in the phase-contrast mode. Images were captured with an Optronics DEI-750 charge-coupled device camera using Matrox Inspector software. Cell diameter was measured using a Leitz stage micrometer $(2 \mathrm{~mm}$, intervals $0.01 \mathrm{~mm})$. At least three images were captured and diameters of all cells $(\sim 5-$ 10 cells/image) determined.

For flow cytometry measurements, cells were resuspended in $10 \%$ FBS-RPMI medium and aliquoted into tubes. Flow cytometry was performed with a Becton Dickinson FACScan (Becton Dickinson Immunocytometry Systems, San Jose, CA). Cellquest V3.1 software (Becton Dickinson) was used for acquisition and analysis of data Forward scatter (FSC) and orthogonal scatter (SSC) were collected using linear amplification. Twenty thousand events were collected in listmode. A bitmap gate was placed around the cell population on the basis of FSC and SSC to eliminate debris and aggregates. Statistics were generated on single-parameter histograms of forward scatter after elimination of debris and aggregates using the bitmap gate.

The diameter range of the nine leukemia cell lines was determined with a phase-contrast light microscope using a micrometer as a scale reference. The diameters determined by light microscopy for all cell lines ranged from 8 to $20 \mu \mathrm{m}$ (Table 1). While some cell lines have

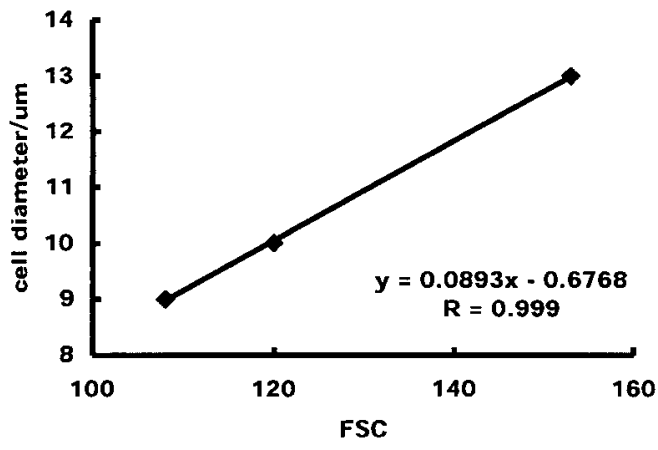

Figure 1. Forward light scatter correlates linearly with cell diameter for leukemia cells. The diameters of three leukemia cell lines (CEM, HL-60, U-937) were measured by conventional light microscopy. Forward light scatter was analyzed using standard flow cytometric techniques. This standard curve was then used to determine the size of the other six cell lines used in the study.

a narrow range of diameters, only $8-12 \mu \mathrm{m}$ (CEM, HL-60, L1210 and Molt-4), others spanned from 8 to $20 \mu \mathrm{m}$ (K-562 and HEL). A true statistically representative distribution of cell diameter is very cumbersome and not realistically achievable with light microscopy. To determine a statistically valid diameter distribution for these nine cell lines, FSC was measured. Polystyrene microspheres (10-20 $\mu \mathrm{m})$ cannot be used as standards to bracket the FSC of the cells because of their very different scattering properties. Thus, to determine the diameter and the diameter distribution of the nine cell lines, we chose three cell lines that had a relatively narrow range and that approached the diameter range of all 9 cell lines under light microscopy. The median diameters from light microscopy of CEM, HL-60 and U-937 cells were used as standards for the calibration curve of the FSC data (Fig. 1). The results of conventional light microscopy and the FSC of the flow cytometer were very comparable, and the standard curve has a regression coefficient of 0.999 . The diameters of the remaining six cell lines were determined using the equation of the standard curve $(\mathrm{y}=0.0893 \mathrm{x}-0.677$, where $\mathrm{y}$ $=$ cell diameter in $\mu \mathrm{m}$, and $\mathrm{x}=$ FSC) (Table 1). The median diameter varies from 9-14 $\mu \mathrm{m}$ for the nine cell lines. The range was determined using the upper and lower $1 \%$ of the gaussian FSC distribution on both sides and correlates well with the range determined by conventional light microscopy.

Photofrin uptake. Cells were exposed to Photofrin $(0,0.9$ or 9 $\mu \mathrm{g} / \mathrm{mL}$ ) at $37^{\circ} \mathrm{C}$ for $45 \mathrm{~min}$ in PBS ( $\mathrm{pH} 7.4$ ). After incubation with Photofrin, cells were washed by centrifugation $(300 \mathrm{~g})$ and resus-

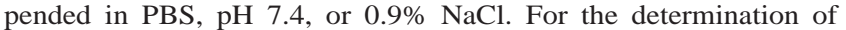
Photofrin uptake (16), Photofrin-exposed cells were resuspended in $2.7 \mathrm{~mL}$ PBS and $300 \mu \mathrm{L}$ Scintigest. Scintigest digests the cells and disaggregates the Photofrin (17). This allows a more accurate assessment of Photofrin uptake because monomers have different spectroscopic properties than dimers and oligomers. Samples and standards (various Photofrin concentrations in PBS) were heated at $60^{\circ} \mathrm{C}$ in the dark for $24 \mathrm{~h}$. Photofrin was determined with a Perkin-Elmer LS50B fluorometer; excitation $402 \mathrm{~nm}$ and emission $620 \mathrm{~nm}$. The cells not exposed to Photofrin were used as the blank control. Photofrin concentrations ranging from $5 \mathrm{ng}$ to $2.5 \mu \mathrm{g} / 3 \mathrm{~mL}$ in buffer were used to construct a standard curve. Standards were treated identically to the cell samples, i.e. Scintigest and heat. Fluorescence quenching occurs above $1 \mu \mathrm{g} / 3 \mathrm{~mL}$ Photofrin. Thus, all cell samples were diluted as necessary so that the fluorescence intensity was in the linear range of the standard curve. Protein was analyzed using the Lowry assay (18).

DBI and total lipid determination. The DBI and total lipid of all cell lines were determined following Wagner et al. (14). Briefly, cells $\left(2 \times 10^{6}\right)$ were washed and extracted with chloroform: methanol 2:1 (vol/vol). After alkaline hydrolysis, fatty acids in the saponifiable fraction were methylated and the methylesters analyzed by gas-liquid chromatography.

Membrane permeability. Trypan blue dye exclusion was used to determine membrane permeability. Cells $(4 \times 10 \% / \mathrm{mL})$ were ex- 


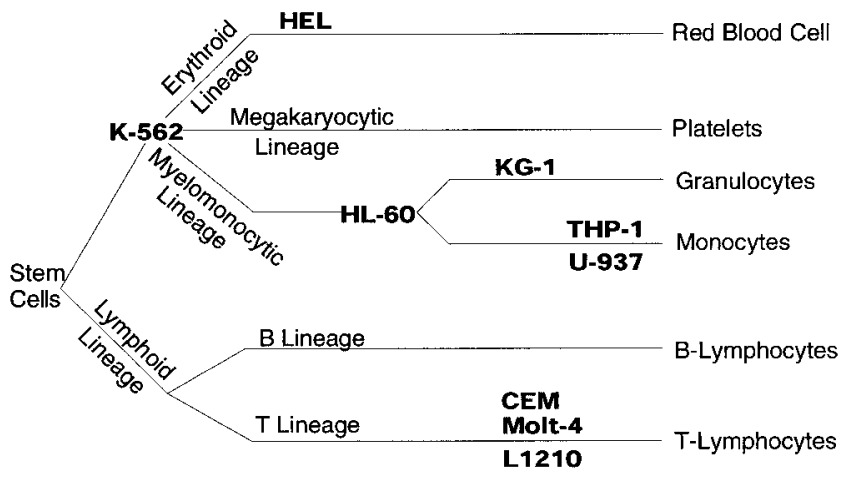

Scheme 1. The relationship of the differentiation pathways for the nine leukemia cell lines used in this study. The eight human and one murine (L1210) cell lines are shown in bold. This scheme is suggestive only and is based on information provided in the ATCC Cell Lines and Hybridomas Catalog, 8th ed. 1994.

posed to Photofrin for 45 min, washed and resuspended in $1 \mathrm{~mL}$ PBS. Ascorbic acid $(100 \mu M)$ and $\mathrm{FeSO}_{4}(5 \mu M)$ were added to 500 $\mu \mathrm{L}$ cell sample $\left(2 \times 10^{6}\right.$ cells $)$ to catalyze radical production from lipid hydroperoxides and placed into one well of a 48 well dish. The dish was placed onto a light box $\left(5 \mathrm{~J} / \mathrm{m}^{2} \mathrm{~s}\right)$ and cells exposed to light up to $32 \mathrm{~min}$. Twenty microliter aliquots were removed every 2 min, mixed with $80 \mu \mathrm{L}$ trypan blue solution $(0.2 \%)$, and cells with membrane damage were counted under a microscope. The light box used for this experiment was equipped with a circular Sylvania light bulb (daylight, $22 \mathrm{~W}$ ) covered with a light diffuser that is impermeable to UV. The intensity was measured with a Yellow Spring Instrument 65 A Radiometer with the 6551 probe. All samples were places in the same marked positions on the light box that provided an even fluence rate.

Fatty acid modification. K-562, U-937 and CEM cells were grown in $10 \%$ FBS-RPMI medium supplemented with $32 \mu M$ docosahexaenoic acid, 22:6 $\omega$ (DHA) for $48 \mathrm{~h}$. Cells were washed twice first in RPMI-1640 medium and then in PBS by centrifugation (300 g). Upon resuspension, cell density was adjusted for trypan blue (4 $\times 10^{6}$ cells $\left./ \mathrm{mL}\right)$ or EPR experiments $\left(8 \times 10^{6}\right.$ cells $\left./ \mathrm{mL}\right)$.

EPR experiments. Cells $\left(8 \times 10^{6} / \mathrm{mL}\right)$ were incubated with Photofrin for $45 \mathrm{~min}$, washed and resuspended in $1 \mathrm{~mL} 0.9 \% \mathrm{NaCl}$. An aliquot of $500 \mu \mathrm{L}$ was mixed with POBN (25 mM), ascorbic acid $(100 \mu M)$ and $\mathrm{FeSO}_{4}(5 \mu M)$ and placed into a TM EPR quartz flat cell. Ferrous iron and ascorbic acid was needed to initiate radical formation from lipid hydroperoxides. Cells were exposed to visible light (tungsten, $180 \mathrm{~J} / \mathrm{m}^{2} \mathrm{~s}$ ), and the POBN radical adduct EPR signal intensity was monitored versus time. Each data point represents the signal-averaged result of five scans of the low field doublet of the POBN/lipid-derived radical adduct spectrum. The first five scans were performed in the dark.

\section{RESULTS AND DISCUSSION}

\section{The nine leukemia cell lines studied}

In this study, one murine and eight human leukemia cell lines were used. They can be divided into different lineages (Scheme 1). CEM, Molt-4 and L1210 (murine) cells represent the lymphoid lineage. They are T-lymphoblast-like cells. The K-562 and HEL cells are erythroid cells. The K562 cells can be differentiated into progenitors of erythrocytic, granulocytic and monocytic series. The HL-60 is a promyelocytic cell line. Vitamin $\mathrm{D}_{3}$ can differentiate the HL60 cells beyond the promyelocytic stage into macrophages and monocytes. The KG-1 cells resemble myelogenous cells with a predominance of myeloblasts and promyelocytes. A small percentage of the cells are mature granulocytes; macrophages and eosinophils can be present. The THP-1 and U-

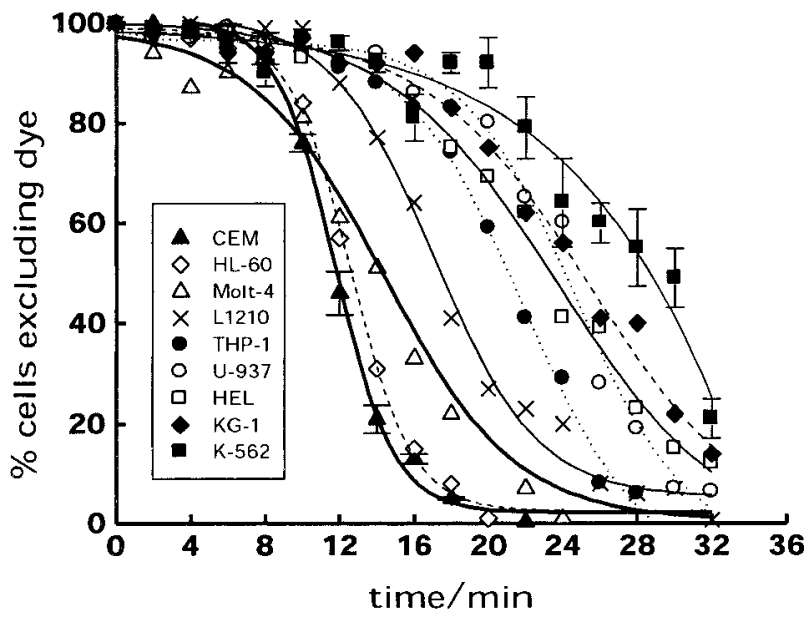

Figure 2. Membrane permeability after Photofrin photosensitization appears to be dependent on cell line and cell lineage. Trypan blue dye exclusion of leukemia cells $\left(4 \times 10^{6} / \mathrm{mL}\right)$ treated with Photofrin $(0.9 \mu \mathrm{g} / \mathrm{mL})$ for $45 \mathrm{~min}$ in PBS. The $\mathrm{Fe}^{2+}(5 \mu M)$ and ascorbate $(100 \mu M)$ were added to the cell suspension in PBS, pH 7.4, and then illuminated with visible light $\left(5 \mathrm{~J} / \mathrm{m}^{2} \mathrm{~s}\right)$. Experiments were done in triplicate. Standard errors are only shown for CEM and K-562 cells for clarity of figure. These uncertainties are typical for all experiments. The curves were fit using the Boltzman/sigmoidal curve fitting function of Microcal ${ }^{\mathbb{T W}}$ Origin, version 4.10.

937 are monocyte-like cells. The THP-1 cells can be differentiated into macrophage-like cells and U-937 can be induced to terminal monocytic differentiation by vitamin $\mathrm{D}_{3}$ and other compounds.

\section{Changes in membrane permeability with Photofrin photosensitization are cell line dependent}

Because of the hydrophobic nature of Photofrin, it locates in cell membranes $(19,20)$. Upon light exposure, it produces ${ }^{1} \mathrm{O}_{2}(2,3)$ that can oxidize polyunsaturated lipids forming lipid hydroperoxides ( $\mathrm{LOOH})$. This oxidative damage can change the membrane permeability that can be detected by trypan blue dye uptake. Cells, whose membranes are intact, exclude trypan blue; when the membrane is damaged, trypan blue can enter the cell. The membranes of different cell lines can vary greatly in their composition and with this in their susceptibility to oxidation. As shown in Fig. 2, membrane permeability after Photofrin photosensitization is cell line dependent. The $t_{50 \%}$, the time when $50 \%$ of the cells exclude trypan blue, ranges from $11.8 \mathrm{~min}$ (CEM cells) to $28.7 \mathrm{~min}$ (K-562 cells) (Table 2). Interestingly, $\mathrm{t}_{50 \%}$ of lymphoid cells (CEM, MOLT-4 and L1210) are $\leq 20 \mathrm{~min}$, while the $t_{50 \%}$ of the myelomonocytic and erythroid cell lines are $>20 \mathrm{~min}$ (with the exception of the HL-60 cells, $13 \mathrm{~min}$ ). Various factors that could produce this difference in membrane damage are examined below.

\section{Photofrin uptake in leukemia cells is dose and cell line dependent}

Photofrin uptake is dependent on the extracellular environment (e.g. PBS, medium, medium $+\mathrm{FBS}$ ), on $\mathrm{pH}$ and on time of exposure $(17,21,22)$. To compare Photofrin phototoxicity in different cells, all nine cell lines were exposed under the same conditions and Photofrin uptake was deter- 
Table 2. The $\mathrm{t}_{50 \%}$ and Photofrin uptake for leukemia cells*

\begin{tabular}{|c|c|c|c|c|}
\hline Cell line & $\begin{array}{c}\mathrm{t}_{50 \%} / \min \dagger \text { using } 0.9 \mu \mathrm{g} \\
\text { Photofrin } / \mathrm{mL}\end{array}$ & $\begin{array}{l}\mathrm{t}_{50 \%} / \mathrm{min} \text { using } 9 \mu \mathrm{g} \\
\text { Photofrin } / \mathrm{mL}\end{array}$ & $\begin{array}{c}\text { ng Photofrin } / 10^{6} \text { cells using } \\
0.9 \mu \mathrm{g} \text { Photofrin } / \mathrm{mL}\end{array}$ & $\begin{array}{l}\text { ng Photofrin } / 10^{6} \text { cells } \\
\text { using } 9 \mu \mathrm{g} \text { Photofrin } / \mathrm{mL}\end{array}$ \\
\hline CEM & 11.8 & n.d. $\neq$ & $58 \pm 0.4$ & $490 \pm 3$ \\
\hline Molt-4 & 14.4 & n.d. & $57 \pm 1$ & $458 \pm 5$ \\
\hline L1210 & 17.4 & 3.7 & $49 \pm 0.4$ & $438 \pm 7$ \\
\hline HL-60 & 12.7 & 3.2 & $82 \pm 1$ & $460 \pm 2$ \\
\hline THP-1 & 21.3 & n.d. & $64 \pm 1$ & $482 \pm 7$ \\
\hline U-937 & 24.3 & 5.3 & $56 \pm 0.1$ & $338 \pm 2$ \\
\hline KG-1 & 25.2 & n.d. & $73 \pm 4$ & $420 \pm 24$ \\
\hline HEL & 23.6 & n.d. & $79 \pm 1$ & $872 \pm 5 \S$ \\
\hline K-562 & 28.7 & 4.7 & $59 \pm 1$ & $332 \pm 14$ \\
\hline
\end{tabular}

* Results are the mean of at least three independent experiments.

$\dagger$ The $\mathrm{t}_{50 \%}$ is the time when $50 \%$ of the cells exclude trypan blue during Photofrin and light exposure. The data were derived from Fig. 2. Leukemia cells $\left(4 \times 10^{6} / \mathrm{mL}\right)$ were treated with Photofrin $(0.9$ or $9 \mu \mathrm{g} / \mathrm{mL})$ for $45 \mathrm{~min}$ in PBS. The $\mathrm{Fe}^{2+}(5 \mu M)$ and ascorbate $(100 \mu M)$ were added to the cell suspension in PBS, $\mathrm{pH} 7.4$, and illuminated with visible light $\left(5 \mathrm{~J} / \mathrm{m}^{2} \mathrm{~s}\right)$.

$\$$ Not determined.

§Because the uptake value for the HEL cell line differs significantly from the other 8 cell lines, we confirmed the data by additional measurements $(n=6)$.

mined for each cell line. Exposing the cells to $0.9 \mu \mathrm{g}$ Photofrin/mL in PBS buffer for 45 min resulted in comparable amounts of Photofrin per $10^{6}$ cells for CEM, K-562, Molt-4 and U-937 (Table 2). The $\mathrm{t}_{50 \%}$ for CEM (58 ng Photofrin/ $10^{6}$ cells) and K-562 (59 ng Photofrin/106 cells) differs by a factor of 2.4. Thus, there must be other factors playing a role in the differences observed in membrane permeability induced by Photofrin.

\section{Membrane permeability correlates inversely with total cellular lipid}

Singlet oxygen can add to double bonds of fatty acid chains to form hydroperoxides. These hydroperoxides can undergo radical chain reactions in the presence of metals, leading to fragmentation of the lipids and damage to the cell membranes.

Table 3. Double bond index, total lipid, protein and cell size*

\begin{tabular}{lrccc}
\hline \multicolumn{1}{c}{ Cell line } & $\begin{array}{c}\text { Total lipid } \\
\left(\mu \mathrm{g} / 10^{6} \text { cells }\right)\end{array}$ & DBI $\dagger$ & $\begin{array}{c}\text { Protein } \\
\left(\mu \mathrm{g} / 10^{6} \text { cells }\right)\end{array}$ & $\begin{array}{c}\text { Cell volume } \\
\left(\mu \mathrm{m}^{3}\right)\end{array}$ \\
\hline CEM & $4 \pm 0.4$ & $0.47 \pm 0.10$ & $45 \pm 7$ & 200 \\
HEL & $14 \pm 1.2$ & $0.62 \pm 0.02$ & $177 \pm 1$ & 486 \\
Molt-4 & $6 \pm 0.6$ & $0.63 \pm 0.03$ & $107 \pm 15$ & 406 \\
L1210 & $8 \pm 0.5$ & $0.73 \pm 0.10$ & $170 \pm 15$ & 308 \\
K-562 & $18 \pm 1$ & $0.76 \pm 0.04$ & $299 \pm 12$ & 802 \\
THP-1 & $12 \pm 0.2$ & $0.79 \pm 0.01$ & $112 \pm 18$ & 535 \\
U-937 & $13 \pm 1$ & $0.95 \pm 0.02$ & $134 \pm 45$ & 602 \\
KG-1 & $13 \pm 0.2$ & $1.21 \pm 0.01$ & $75 \pm 5$ & 300 \\
HL-60 & $9 \pm 0.3$ & $1.23 \pm 0.07$ & $122 \pm 7$ & 277 \\
K-562 DHA & $28 \pm 3.3$ & $2.38 \pm 0.08$ & & \\
enriched & & & & \\
U-937 DHA & $22 \pm 1.1$ & $2.91 \pm 0.06$ & & \\
$\quad$ enriched & & & & \\
\hline
\end{tabular}

*Results are the mean of at least three independent experiments.

$\dagger \mathrm{DBI}$, the average number of double bonds per fatty acid chain in a lipid ensemble (such as a cell membrane).

$\ddagger$ Cell volume was calculated assuming cells are spherical. Numbers represent the median volume.
The total lipid content of all nine cell lines varies greatly (Table 3). The CEM cells, the smallest cell line, have the lowest lipid content ( $4 \mu \mathrm{g} / 10^{6}$ cells); K-562, the biggest cell line, has the highest lipid content $\left(18 \mu \mathrm{g} / 10^{6}\right.$ cells). Although lipids can be a target for singlet oxygen, here they seem to protect the cell against ${ }^{1} \mathrm{O}_{2}$ damage. Resistance to Photofrin phototoxicity $\left(\mathrm{t}_{50 \%}\right)$ increases with increasing lipid content (Fig. 3). There is a strong positive correlation between $t_{50 \%}$ and total lipid ( $R=0.94)$ (Fig. 3A); the correlation for the lymphoid cells is ideal $(R=0.999)$ (Fig. 3C). The correlation for the four cell lines with the same Photofrin content per cell is $R=0.993$ (Fig. 3B). These data suggest that lipids can protect the plasma membrane from ${ }^{1} \mathrm{O}_{2}$ damage.

\section{Membrane permeability weakly correlates with DBI}

The lipids of a cell contain both saturated and unsaturated fatty acids. Singlet oxygen can add to carbon-carbon double bonds of fatty acids to form hydroperoxides. The higher the number of double bonds, the higher the oxidizability of a lipid. The average number of double bonds per fatty acid chain in a lipid ensemble (such as a cell membrane) can be expressed as the DBI. The nine cell lines investigated vary greatly in their DBI (0.47 CEM to $1.23 \mathrm{HL}-60)$ (Table 3). Therefore, their susceptibility to lipid peroxidation initiated by ${ }^{1} \mathrm{O}_{2}$ should be different. Looking at all nine cell lines, cells with a higher DBI, which means higher oxidizability of the cellular lipids, show a very weak if any correlation with $\mathrm{t}_{50 \%}$ (Fig. 4A). However, if the four cell lines that have the same amount of Photofrin are examined, there is a good positive correlation of $t_{50 \%}$ versus $\mathrm{DBI}(\mathrm{R}=0.72)$ (Fig. 4B). If $\mathrm{DBI}$ is an important parameter for the phototoxicity of Photofrin, one would expect an inverse correlation; increasing the DBI by enrichment of cell membranes with PUFA should result in increased membrane permeability induced by Photofrin and light. To determine the importance of DBI, i.e. lipid unsaturation, in lipid peroxidation induced by Photofrin and light, we increased the DBI of cells by supplementation of media with DHA, a fatty acid with six double 
A

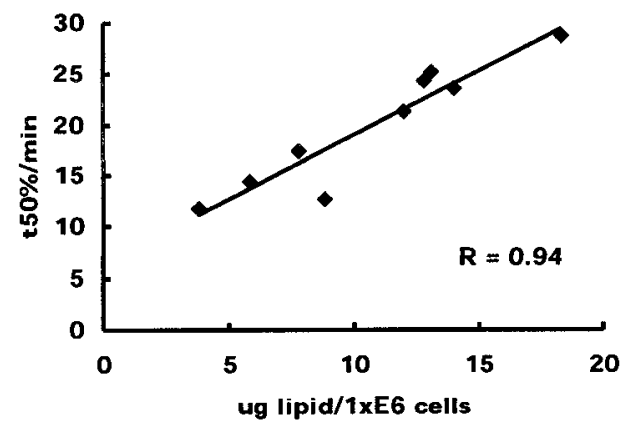

B

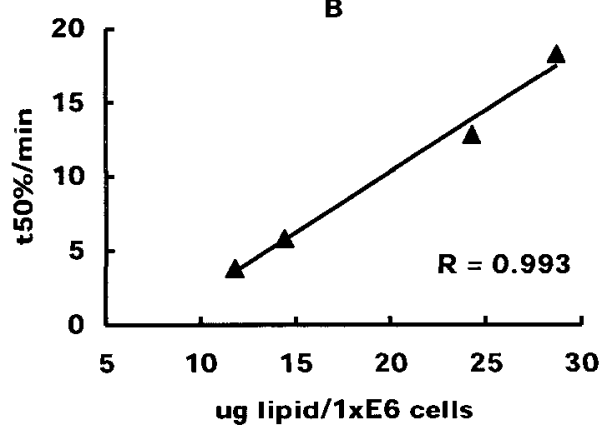

C
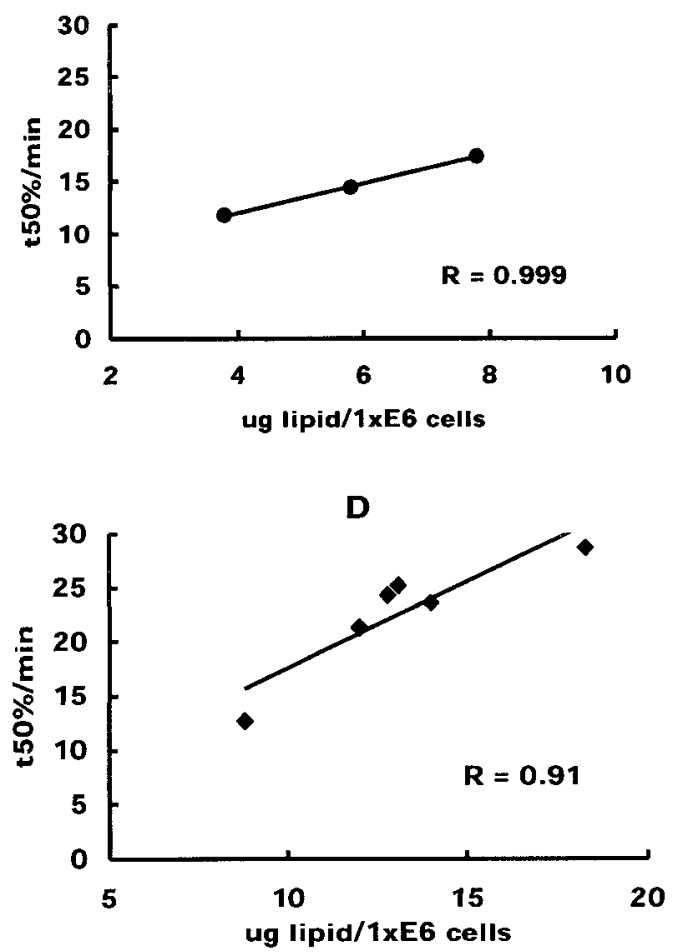

Figure 3. Correlation of total lipid and membrane permeability in leukemia cells after exposure to Photofrin and light. The $\mathrm{t}_{50 \%}$ is the time when $50 \%$ of the cells exclude trypan blue during Photofrin and light exposure. (A) All nine leukemia cell lines; (B) CEM, K562, Molt-4, and U-937 cells (they have comparable amount of Photofrin); (C) lymphoid cell lines (CEM, L1210 and Molt-4); (D) myelomonocytic and erythroid cell lines. The data are derived from Fig. 2 and Table 3.
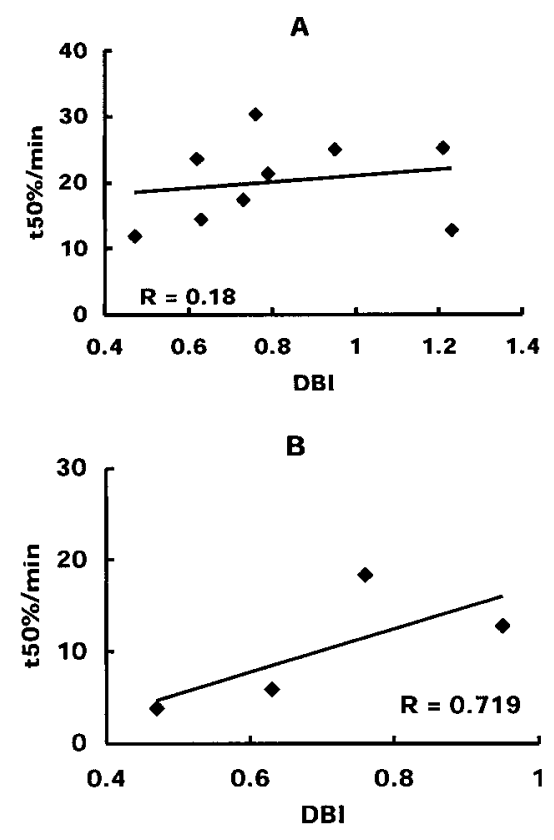

C

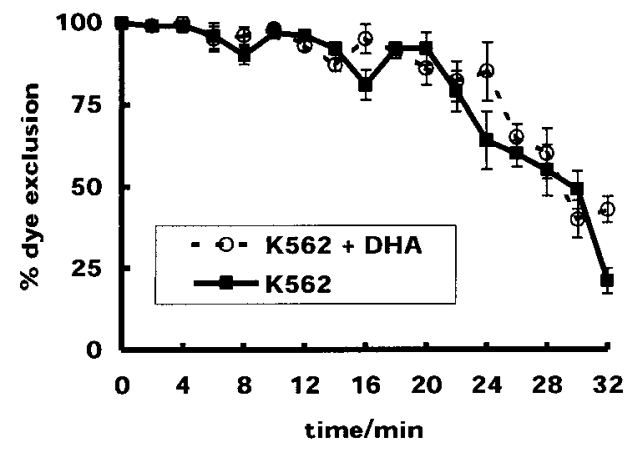

D

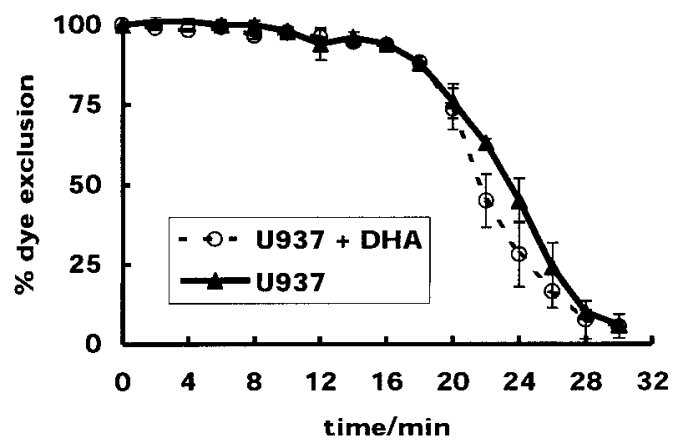

Figure 4. Membrane permeability in leukemia cells after exposure to Photofrin and light is not influenced by lipid unsaturation. The $\mathrm{t}_{50 \%}$ is the time when $50 \%$ of the cells exclude trypan blue during Photofrin and light exposure. (A) All nine leukemia cell lines (data are derived from Fig. 2 and Table 3); (B) CEM, K-562, Molt-4 and U-937 cells (they have the same amount of Photofrin/cell); (C) K562 cells enriched with DHA for $48 \mathrm{~h}$ prior to Photofrin $(0.9 \mu \mathrm{g} /$ $\mathrm{mL}$ for $45 \mathrm{~min}$ in PBS) photosensitization; (D) U-937 cells enriched with DHA for $48 \mathrm{~h}$ prior to Photofrin $(0.9 \mu \mathrm{g} / \mathrm{mL}$ for $45 \mathrm{~min}$ in PBS) photosensitization. Experiments were done in triplicate. 
bonds. This supplementation increased the total DBI of K562 and U-937 cells three-fold (Table 3). Analysis of the phospholipids that represent the membrane lipids shows a substantial increase in membrane DBI (K-562: DBI [phospholipid] increased from $0.83 \pm 0.06$ to $1.20 \pm 0.02$; U-937 increased from $1.09 \pm 0.12$ to $1.87 \pm 0.20)$. This increase in DBI did not result in an increase in membrane permeability compared to unsupplemented cells (Fig. 4C,D). These data suggest that the DBI has a minor influence on membrane permeability induced by singlet oxygen in these nine leukemia cell lines; thus, there must be additional factors playing a significant role in ${ }^{1} \mathrm{O}_{2}$ toxicity.

\section{Protein protects leukemia cells from Photofrin photosensitization}

It has been demonstrated that ${ }^{1} \mathrm{O}_{2}$ produced in a cell membrane readily diffuses into the neighboring aqueous environments inside and outside the cell (23). Singlet oxygen can be quenched by water, lipids, proteins, nucleic acids and other small molecules. When ${ }^{1} \mathrm{O}_{2}$ is produced in a cell membrane, up to $80 \%$ can be quenched by protein; unsaturated lipids can account for up to $7 \%$ of the quenching, depending on cell type $(12,13)$. The quenching of ${ }^{1} \mathrm{O}_{2}$ by unsaturated lipids is dominated by chemical processes that result in the formation of lipid hydroperoxides that cause membrane damage; quenching by protein can be both chemical and physical, depending on the amino acids involved.

The protein content and cell size of the nine cell lines vary greatly. Protein content ranges from $45 \mu \mathrm{g} / 10^{6}$ for CEM cells to $299 \mu \mathrm{g} / 10^{6}$ for $\mathrm{K}-562$ cells; the cell diameter ranges from $9 \mu \mathrm{m}$ (CEM) to $14 \mu \mathrm{m}(\mathrm{K}-562)$ (Table 1). Resistance to Photofrin phototoxicity $\left(\mathrm{t}_{50 \%}\right)$ increases with increasing protein (Fig. 5A). These observations are consistent with the known ability of some amino acids to quench singlet oxygen (8-11). Chemical quenching reactions, such as occur with cysteine, tryptophan and methionine, could be detrimental, while physical quenching, such as with histidine, would offer protection. The myelomonocytic and erythroid cells show only a weak correlation $(R=0.49)$ between $\mathrm{t}_{50 \%}$ and protein content (Fig. 5D).

In contrast, the remarkable positive correlation $(R=$ 0.999, Fig. 5C) of $\mathrm{t}_{50 \%}$ for the lymphoid cell lines with cellular protein levels and the correlation $(R=0.937$, Fig. 5B) for the four cell lines that have the same amount of Photofrin per cell suggest that the membrane-associated proteins of these cells offer a unique mode of protection. The K-562 cells have the highest protein to DBI ratio (393 $\mu \mathrm{g}$ protein/ $10^{6}$ cells : DBI) and also the highest $t_{50 \%}$, while CEM and HL-60 cells each have a low ratio $\left(95 \mu \mathrm{g}\right.$ protein $/ 10^{6}$ cells : DBI) and a correspondingly low $\mathrm{t}_{50 \%}$. Therefore a high ratio of protein to unsaturated lipid in a cell might be important for protection against ${ }^{1} \mathrm{O}_{2}$. Lipids and proteins provide a competing environment for ${ }^{1} \mathrm{O}_{2}$; different cell lines present different environments and respond accordingly.

\section{Membrane susceptibility to photodamage by Photofrin decreases with increasing cell size}

The size of the nine leukemia cell lines measured as volume (Table 3) ranges from $200 \mu \mathrm{m}^{3}$ (CEM) to $800 \mu \mathrm{m}^{3}$ (K-562). Resistance to Photofrin phototoxicity $\left(\mathrm{t}_{50 \%}\right)$ increases with
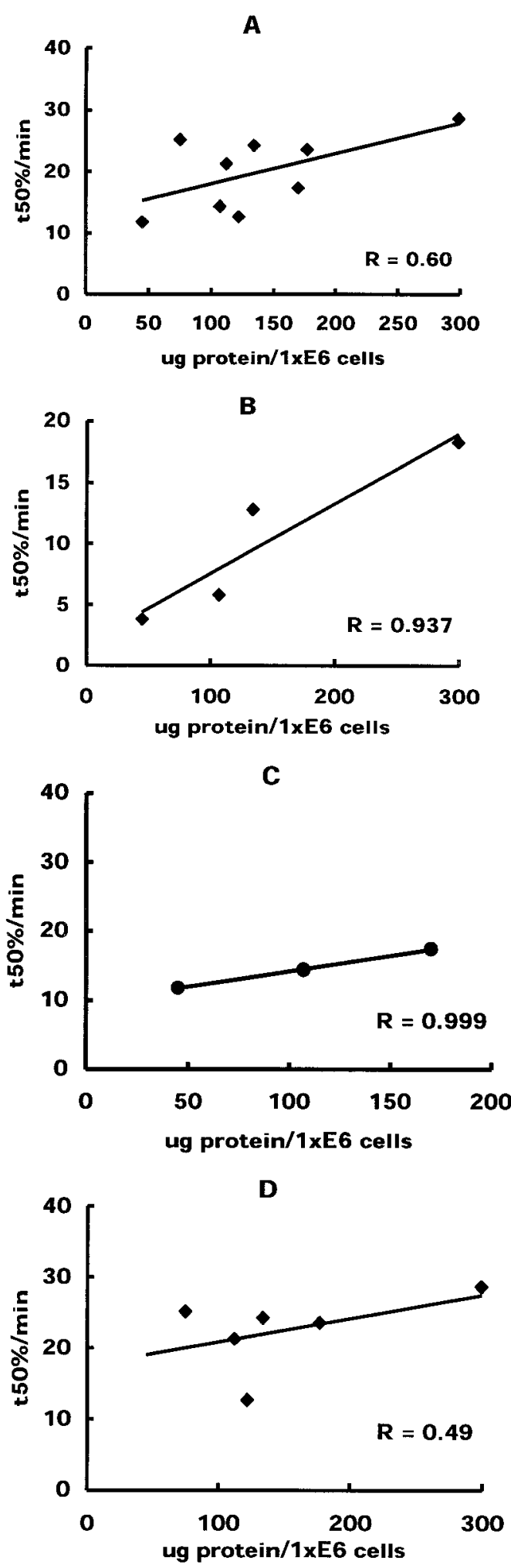

Figure 5. Protein protects leukemia cells from Photofrin photosensitization. The $\mathrm{t}_{50 \%}$ is the time when $50 \%$ of the cells exclude trypan blue during Photofrin and light exposure. (A) All nine cell lines; (B) CEM, K-562, Molt-4 and U-937 cells (they have comparable amount of Photofrin); (C) lymphoid cell lines; (D) myelomonocytic and erythroid cell lines. The data derived from Fig. 2 and Table 3. 
Figure 6. Membranes of bigger cells are less sensitive to Photofrin photosensitization. The $\mathrm{t}_{50 \%}$ is the time when $50 \%$ of the cells exclude trypan blue during Photofrin and light exposure. (A) Correlation between membrane permeability and cell size; (B) correlation between total lipid content of cells and cell size; (C) correlation between cell protein and cell size; (D) correlation between DBI and cell size for all nine leukemia cells; (E) correlation between DBI and cell size for myelomonocytic and erythroid cells; (F) correlation between Photofrin uptake and cell size. The data derived from Fig. 2 and Tables 2 and 3 .
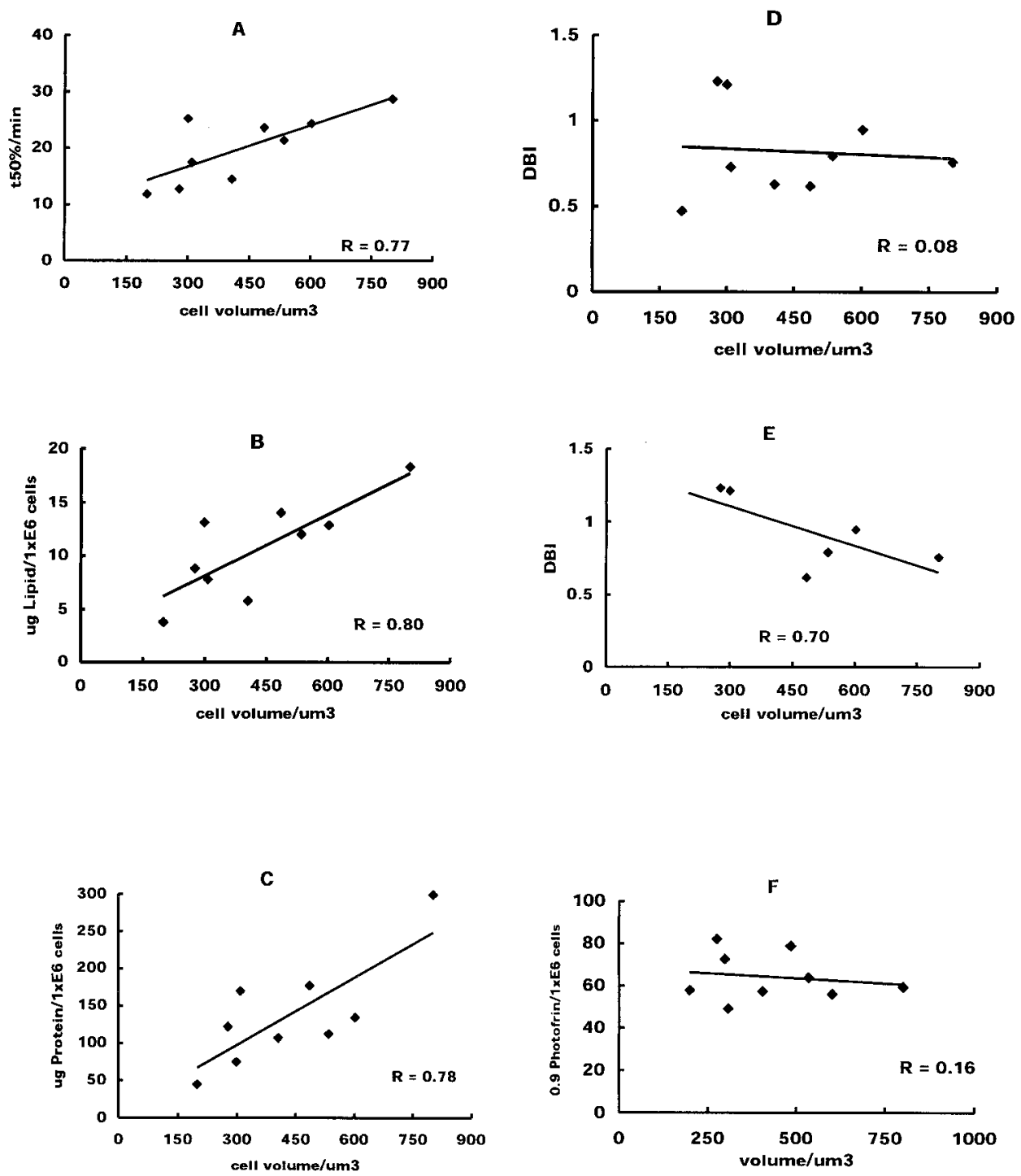

increasing cell volume (Fig. 6A). Variants of RIF-1 cells with larger diameters showed a tendency to increase resistance, but unfortunately actual cell volumes were not determined (24). With increasing cell volume, the total lipid and total protein content naturally increases (Fig. 6B,C). In contrast to the total lipid, DBI for all nine cell lines shows no change with volume (Fig. 6D). However, when the subset consisting of only the myelomonocytic and erythroid cell lines is examined, a decrease in the DBI with increasing volume is seen (Fig. 6E). Photofrin uptake does not change with increasing volume (Fig. 6F). Thus bigger cells compared to smaller cells should produce the same amount of ${ }^{1} \mathrm{O}_{2}$ because they have comparable amounts of Photofrin. However, bigger cells are less damaged because the levels of proteins and total lipids are higher. While the lipid content of larger cells is greater, the degree of unsaturation is less (Fig. 6E) making them less susceptible to lipid peroxidation. Thus, membrane damage induced by Photofrin photosensitization is a function of lipid, protein and Photofrin content of the cell.

\section{Radical formation increases with increasing DBI}

Singlet oxygen reacts with unsaturated lipids forming lipid hydroperoxides ( $\mathrm{LOOH})$. These hydroperoxides can react with ferrous iron initiating free radical chain reactions producing oxygen- (LO', OLOO') and carbon- $\left({ }^{\circ} \mathrm{L}_{\mathrm{d}}\right)$ centered radicals. The rate of these oxidations should increase with increasing DBI of the cells. Using EPR with POBN as a spin trap, we detected carbon-centered radicals formed as a result of the lipid peroxidation processes initiated by Photofrin photosensitization (Fig. 7A). This radical formation increases with duration of light exposure and reaches a plateau for most cell lines at approximately $12 \mathrm{~min}$. Radical formation is cell line dependent; HL-60 cells produce the highest flux and HEL cells the lowest. No correlation between radical formation and total lipid was found (Fig. 8A); when cell lines with similar levels of Photofrin are compared, DBI correlates well with radical formation $(R=0.946)$ (Fig. 8C).

The DBI of cells can be increased by supplementing the growth media with linoleic acid (18:2) and highly unsatu- 


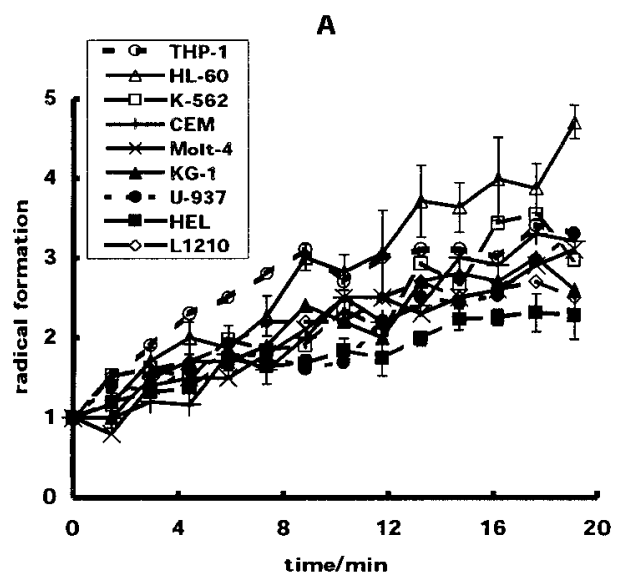

B

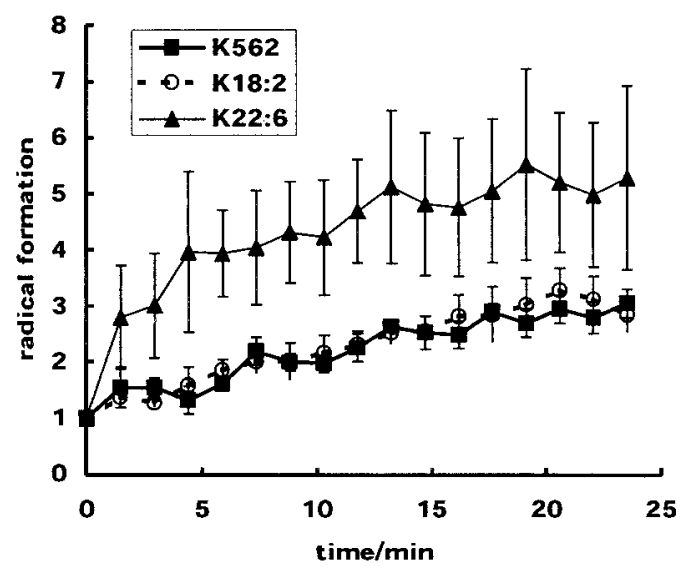

Figure 7. Radical formation from leukemia cells exposed to Photofrin and light is cell line dependent. The EPR signal intensity of POBN/L $\mathrm{L}_{\mathrm{d}}$ produced from cells $\left(8 \times 10^{6} / \mathrm{mL}\right)$ were treated with Photofrin $(0.9 \mu \mathrm{g} / \mathrm{mL})$ for $45 \mathrm{~min}$ in PBS. The $\mathrm{Fe}^{2+}(5 \mu M)$ and ascorbate $(100 \mu M)$ were added to the cell suspension in $0.9 \% \mathrm{NaCl}$ and the sample was then illuminated with visible light $\left(180 \mathrm{~J} / \mathrm{m}^{2} \mathrm{~s}\right)$ in the cavity. (A) Different leukemia cells $\left(8 \times 10^{6}\right.$ cells $\left./ \mathrm{mL}\right)$; error bars are only shown for HL-60 and HEL for clarity of figure. (B) Linoleic acid (K18:2)- and DHA (K22:6)-enriched K-562 cells treated with Photofrin $(9 \mu \mathrm{g} / \mathrm{mL})$. Experiments were done in triplicate. Standard errors are only shown for HEL and HL-60 cells for clarity of figure. These uncertainties are typical for all experiments.

rated DHA (22:6). This increase in unsaturation should result in greater radical formation. Enrichment of K-562 cells with linoleic acid results in an increase in the DBI from $0.76 \pm$ 0.04 to $0.92 \pm 0.01$ while DHA results in an increase in the DBI from $0.76 \pm 0.05$ to $2.38 \pm 0.08$ (Table 3 ). The increase in DBI is not high enough in linoleic acid-enriched cells to have a detectable effect on the radical flux. However, DHAenriched cells produced an increase in the observed radical flux (Fig. 7B). This is in contrast to membrane permeability that was not influenced by DHA enrichment in K-562 cells (Fig. 4C,D). While the membrane permeability is influenced by the amount of unsaturated lipids in the plasma membrane, the radical flux observed can derive from all cell membranes that bind Photofrin (mitochondria, plasma membrane, endoplasmic reticulum) and the neutral lipids stored in droplets in the cytosol. These results indicate that unsaturated lipids are a target for the ${ }^{1} \mathrm{O}_{2}$ that is produced during Photofrin photosensitization.

Protein does not easily undergo oxidation by radical chain reactions. Indeed, radical formation does not increase with increasing protein levels (Fig. 8D) or increasing volume (Fig. 8E). These results are comparable with the membrane permeability. The proteins appear to quench mainly physically because no protein radicals were detected.

Thus, radical formation induced by ${ }^{1} \mathrm{O}_{2}$ appears to be a function of lipid content of the cell. Highly unsaturated lipids increase radical formation.

\section{CONCLUSIONS}

The oxidative damage that results from ${ }^{1} \mathrm{O}_{2}$ exposure is dependent on cell line. Different cell lines present different environments and respond accordingly. Using Photofrin as a source of ${ }^{1} \mathrm{O}_{2}$, we examined various factors in cells that influence the toxicity of ${ }^{1} \mathrm{O}_{2}$.

Photofrin. We observed that cell lines with comparable amounts of Photofrin/cell had different susceptibility to damage by ${ }^{1} \mathrm{O}_{2}$.

Lipids. Saturated lipids are not a target for ${ }^{1} \mathrm{O}_{2}$ while unsaturated lipids can be easily oxidized. Oxidation of PUFA leads to $\mathrm{LOOH}$ formation. If no free redox-active metal is available, these $\mathrm{LOOH}$ can accumulate. The $\mathrm{LOOH}$ can be removed by phospholipase $\mathrm{A}_{2}$ /glutathione peroxidase- 1 (GPx) or phospholipid hydroperoxide GPx (PhGPx) (25). If ferrous iron is available, it can react with $\mathrm{LOOH}$ initiating free radical chain reactions that would be detrimental to the cell. We detected lipid-derived radical formation in all nine leukemia cell lines exposed to Photofrin and light. Increasing the unsaturation of the cell lipids increased the radical formation. Surprisingly we observed no correlation between lipid unsaturation (DBI) and change in membrane permeability $\left(\mathrm{t}_{50 \%}\right)$ after ${ }^{1} \mathrm{O}_{2}$ exposure. Kanofsky (13) has shown that only approximately $7 \%$ of the ${ }^{1} \mathrm{O}_{2}$ produced in membranes is quenched by cellular lipids. This is in agreement with our data that suggest that lipids may not be the primary target for ${ }^{1} \mathrm{O}_{2}$-mediated phototoxicity.

Protein. Proteins appear to quench about $80 \%$ of the ${ }^{1} \mathrm{O}_{2}$ produced in cell membranes (13). Singlet oxygen can be physically quenched by proteins, which results in protection against cell damage. Proteins can also chemically quench ${ }^{1} \mathrm{O}_{2}$. The chemical quenching leads to damage of the protein that can bring about membrane depolarization $(26,27)$ and if severe be lethal. The typical rate constants reported for unsaturated lipids reacting with ${ }^{1} \mathrm{O}_{2}$ in various organic solvents is on the order of $10^{5} \mathrm{M}^{-1} \mathrm{~s}^{-1}(8)$. In contrast, rate constants for ${ }^{1} \mathrm{O}_{2}$ reacting with proteins are considerably greater. For example: histidine $k>10^{7} M^{-1} \mathrm{~s}^{-1}$; tryptophan $k>10^{7} M^{-1}$ $\mathrm{s}^{-1}$; cysteine $k=10^{8} M^{-1} \mathrm{~s}^{-1}$; albumin $k \approx 2-5 \times 10^{8} M^{-1}$ $\mathrm{s}^{-1} ; \mathrm{Cu}$ and $\mathrm{Zn}$ containing superoxide dismutase $k \approx 10^{9}$ $M^{-1} \mathrm{~s}^{-1}$. We found an inverse correlation between membrane permeability changes $\left(\mathrm{t}_{50 \%}\right)$ and cellular protein suggesting that proteins play an important role in protection against ${ }^{1} \mathrm{O}_{2}$ toxicity.

Cell size. A remarkable observation is that larger cells are 
Figure 8. Radical formation in leukemia cells exposed to Photofrin and light does not change with increasing protein, lipid content or size of the cell. (A) Increase in total lipid does not influence radical formation. (B) Increased DBI produces only slightly higher radical flux in the nine cell lines. (C) Increased DBI produces a higher radical flux when cell lines with the same amount of Photofrin/ cell are compared. (D) Increase in protein does not change radical formation. (E) Cell volume has no influence on radical formation.
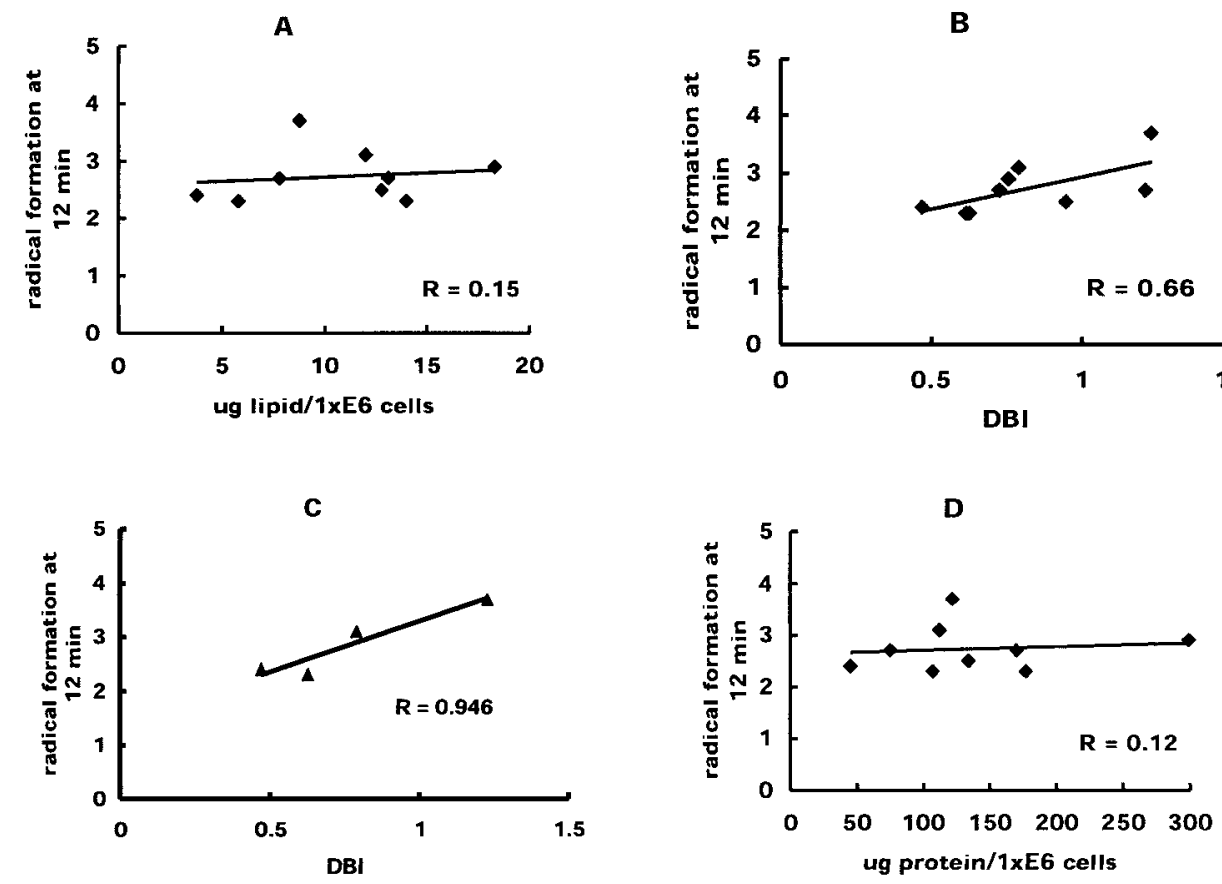

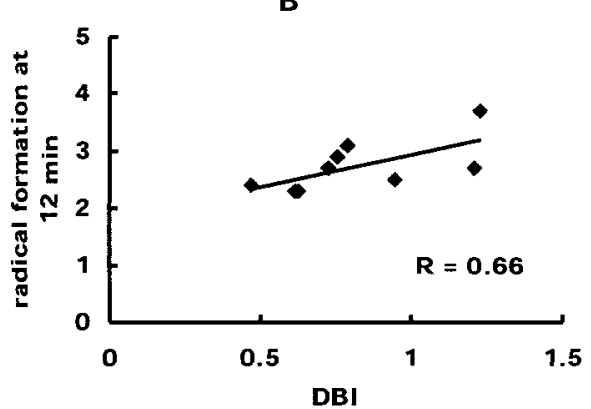

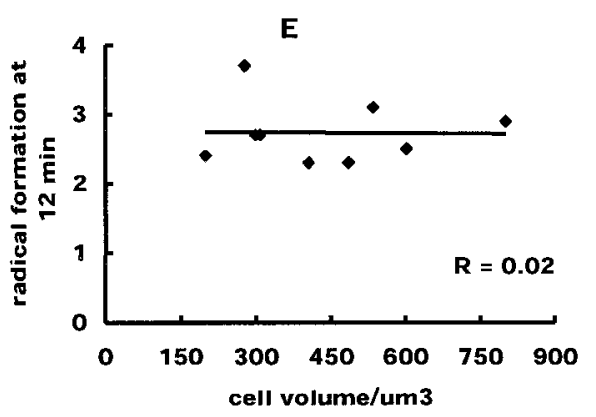

more protected against Photofrin phototoxicity than smaller cells. Under our experimental conditions, the amount of Photofrin uptake was independent of cell size, but as expected the protein and lipid content increases with increasing size. This increase in lipid and protein content provides a larger capacity to quench ${ }^{1} \mathrm{O}_{2}$. Thus, larger cells are more resistant to a given flux of ${ }^{1} \mathrm{O}_{2}$.

If ${ }^{1} \mathrm{O}_{2}$ is generated in tissue, the lipid and protein profile of that tissue will strongly influence the extent of damage produced.

Acknowledgements-We are grateful to Brett A. Wagner, Justin Fishbaugh and Lori Manzel for helpful discussions and support. We thank Dr. A. A. Spector's laboratory for the lipid work. This investigation was supported by National Institute of Health grant CA-66081.

\section{REFERENCES}

1. Briviba, K., L. O. Klotz and H. Sies (1997) Toxic and signaling effects of photochemically or chemically generated singlet oxygen in biological systems. Biol. Chem. 378, 1259-1265.

2. Weishaupt. K. R., C. J. Gomer and T. J. Dougherty (1976) Identification of singlet oxygen as the cytotoxic agent in photoinactivation of a murine tumor. Cancer Res. 36, 2326-2329.

3. Thomas, J. P., R. D. Hall and A. W. Girotti (1987) Singlet oxygen intermediacy in the photodynamic action of membranebound hematoporphyrin derivative. Cancer Lett. 35, 295-302.
4. Thomas, J. P. and A. W. Girotti (1989) Role of lipid peroxidation in hematoporphyrin derivative-sensitized photokilling of tumor cells: protective effects of glutathione peroxidase. Cancer Res. 49, 1682-1686.

5. Porter, N. A., S. E. Caldwell and K. A. Mills (1995) Mechanisms of free radical oxidation of unsaturated lipids. Lipids $\mathbf{3 0}$, 277-290.

6. Paillous, N. and S. Fery-Forgues (1994) Interest of photochemical methods for induction of lipid peroxidation. Biochimie 76, 355-368.

7. Frankel, E. N. (1991) Recent advances in lipid oxidation. J. Sci. Food Agric. 54, 495-511.

8. Wilkinson, F., W. P. Helman and A. B. Ross (1995) Rate constants for the decay and reactions of the lowest electronically excited singlet state of molecular oxygen in solution. An expanded and revised compilation. J. Phys. Chem. Ref. Data 24, 663-1021.

9. Sysak, P. K., C. S. Foote and T. Y. Ching (1977) Chemistry of singlet oxygen-XXV. Photooxygenation of methionine. Photochem. Photobiol. 26, 19-27.

10. Reddi, E., M. A. J. Rodgers, J. D. Spikes and G. Jori (1984) The effect of medium polarity on the hematophorphyrin-sensitized photooxidation of L-tryptophan. Photochem. Photobiol. 40, 415-421.

11. Buettner, G. R. and R. D. Hall (1987) Superoxide, hydrogen peroxide and singlet oxygen in hematoporphyrin derivative-cysteine, -NADH and -light systems. Biochim. Biophys. Acta 923, 501-507.

12. Baker, A. and J. R. Kanofsky (1992) Quenching of singlet ox- 
ygen by biomolecules from L1210 leukemia cells. Photochem. Photobiol. 55, 523-528.

13. Kanofsky. J. R. (1991) Quenching of singlet oxygen by human red cell ghosts. Photochem. Photobiol. 53, 93-99.

14. Wagner, B. A., G. R. Buettner and C. P. Burns (1994) Free radical-mediated lipid peroxidation in cells: oxidizability is a function of cell lipid bis-allylic hydrogen content. Biochemistry, 33, 4449-4453.

15. Buettner, G. R. (1988) In the absence of catalytic metals, ascorbate does not autoxidize at $\mathrm{pH}$ 7: ascorbate as a test for catalytic metals. J. Biochem. Biophys. Methods 16, 20-40.

16. Korbelik, M., J. Hung, S. Lam and B. Palcic (1990) The effects of low density lipoproteins on uptake of Photofrin II. Photochem. Photobiol. 51, 191-196.

17. Korbelik, M. and J. Hung (1991) Cellular delivery and retention of Photofrin II: the effects of interaction with human plasma proteins. Photochem. Photobiol. 53, 501-510.

18. Lowry, O. H., N. J. Rosebrough, A. L. Farr and R. J. Randall (1951) Protein measurement with the Folin phenol reagent. $J$. Biol. Chem. 193, 265.

19. Woodburn, K. W., N. J. Vardaxis, J. S. Hill, A. H. Kaye and D. R. Phillips (1991) Subcellular localization of porphyrins using confocal laser scanning microscopy. Photochem. Photobiol. 54, 725-732.

20. Moan, J. and S. Sommer (1984) Action spectra for hematoporphyrin derivative and Photofrin II with respect to sensitization of human cells in vitro to photoinactivation. Photochem. Photobiol. 40, 631-634.

21. Boehmer, R. M. and G. Morstyn (1985) Uptake of hematoporphyrin derivative by normal and malignant cells: effect of serum, $\mathrm{pH}$, temperature, and cell size. Cancer Res. 45, 5328-5334.

22. Korbelik, M. (1991) Cellular delivery and retention of Photofrin II: the effects of interaction with human plasma proteins. Photochem. Photobiol. 53, 501-510.

23. Baker, A. and J. R. Kanofsky (1993) Time-resolved studies of singlet oxygen emission from L1210 leukemia cells labeled with 5 -( $N$-hexadecanoyl)amino eosin. A comparison with a one-dimensional model of singlet-oxygen diffusion and quenching. Photochem. Photobiol. 57, 720-727.

24. Luna, M. C. and C. J. Gomer (1991) Isolation and initial characterization of mouse tumor cells resistant to porphyrin-mediated photodynamic therapy. Cancer Res. 51, 4243-4249.

25. Antunes, F., A. Salvador and R. E. Pinto (1995) PhGPx and phospholipase $\mathrm{A}_{2} / \mathrm{GPx}$ : comparative importance of the reduction of hydroperoxides in rat liver mitochondria. Free Radicals Biol. Med. 19, 669-677.

26. Specht, K. G. and M. A. J. Rodgers (1990) Depolarization of mouse myeloma cell membranes during photodynamic action. Photochem. Photobiol. 51, 319-324.

27. Specht, K. G. and M. A. J. Rodgers (1991) Plasma membrane depolarization and calcium influx during cell injury by photodynamic action. Biochim. Biophys. Acta 1070, 60-68. 